\title{
BAGAIMANAKAH PENGUASAAN KEMAMPUAN MENULIS TEKS DESKRIPTIF SEDERHANA SISWA MELALUI DISCOVERY LEARNING TERBIMBING BERBANTUAN APLIKASI WEMOJI UNTUK BASIC?
}

\author{
Siti Khodijah Nasution \\ SMP Negeri 4 Depok Jawa Barat, Jalan Merdeka Raya Depok II Tengah, Mekar Jaya, Kec. Sukmajaya, Kota \\ Depok, Jawa Barat 16411, sitikn@ gmail.com
}

Diterima 20 Februari 2020, disetujui 16 April 2020, diterbitkan 30 April 2020

Pengutipan: Nasution, S. K. (2020). Bagaimanakah Pengusaan Kemampuan Menulis Teks Deskriptif Sederhana Siswa Melalui Discovery Learning Terbimbing Berbaantuan Aplikasi Wemoji untuk Basic?. Gema Wiralodra, Vol 11, No 1, Hal 59-73, April 2020

\begin{abstract}
ABSTRAK
Penelitian ini secara umum bertujuan untuk mendeskripsikan penguasaan kemampuan menulis teks deskriptif sederhana siswa melalui discovery learning terbimbing berbantuan aplikasi wemoji untuk basic. Sedangkan tujuan khusus penelitian ini bertujuan untuk (1) mendeskripsikan peningkatan kemampuan menulis siswa; (2) menstimulus siswa menulis kreatif yang menyenangkan melalui aplikasi wemoji untuk basic; (3) melatih siswa berpikir HOTS melalui pembelajaran berbantuan aplikasi wemoji untuk basic. Desain penelitian yang digunakan dalam penelitian ini yakni desain penelitian tindakan kelas. Tindakan yang digunakan yakni dengan discovery learning terbimbing berbantuan aplikasi wemoji untuk basic. Partisipan yang terlibat berjumlah 35 siswa kelas VII-B di Sekolah Menengah Pertama (SMP) Negeri yang ada di Depok, Jawa Barat pada Tahun Pelajaran 2019/2020 semester ganjil. Hasil penelitian menunjukkan ada peningkatakan kemampuan menulis teks deskriptif sederhana siswa. Hal tersebut terlihat dari adanya penguasaan kemampuan menulis teks deskriptif sederhana baik melalui tes maupun non tes, yakni adanya peningkatan kemampuan menulis siswa sebesar 76,4\% dalam hasil tes serta ketuntasan $80 \%$, dikatagorikan hasilnya baik.
\end{abstract}

Kata Kunci: Aplikasi Wemoji, Kemampuan Menulis Teks Deskriptif Sederhana, discoverylearning terbimbing

\begin{abstract}
This study generally aims to describe the mastery of students' ability to write simple descriptive texts through guided discovery learning assisted by the application of Wemoji for Basic. While the specific objectives of this study aim to (1) describe the improvement of students' writing skills; (2) stimulating fun creative writing students through the wemoji application for basic; (3) train students to think HOTS through learning assisted by the Wemoji application for basic. The research design used in this study is classroom action research design. The action used is guided learning assisted with Wemoji for basic applications. Participants involved were 35 students of class VII-B in the Public Middle School (SMP) in Depok, West Java in the 2019/2020 Academic Year odd semester. The results showed there was an increase in students' ability to write simple descriptive texts. This can be seen from the mastery of the ability to write simple descriptive text through tests and non-tests, namely an increase in students' writing ability by $76.4 \%$ in the test results and $80 \%$ completeness, categorized as good results.
\end{abstract}

Keywords: Wemoji Application, Simple Descriptive Text Writing Capability, guided discovery learning 


\section{PENDAHULUAN}

Belajar konstruktivisme menekankan sekali bahwa belajar adalah siswa harus menemukan sendiri dan mentransformasikan informasi kompleks, mengecek infromasi baru dengan aturan-aturan lama dan merevisinya apabila aturan-aturan itu tidak sesuai lagi (Slavin, 2013). Guru tidak hanya sekedar memberikan pengetahuan akan tetapi siswa harus membangun sendiri pengetahuan di dalam benaknya dan guru memberikan kemudahan untuk mencapai pengetahuan tersebut sehingga siswa dapat menemukan dan menerapkan sendiri ide-ide mereka sendiri (Chin \& Osborne, 2008). Salah satu pembelajaran yang berbasis konstruktivisme yakni discovery learning. Discovery learning merupakan salah satu pembelajaran yang direkomendasikan dalam kurikulum 2013.

Pada konteks penelitian ini, penggunaan discovery learning bisa digunakan untuk membantu siswa dalam meningkatkan kemampuan menulis. Idalia Cardoso (2018) Berdasarkan hasil analisis yang telah dilakukan, menyimpulkan bahwa kemampuan siswa dalam menulis narasi mengalami peningkatan. Hal ini dapat diketahui dari nilai menulis narasi yang diperoleh siswa melalui lima aspek penilaian dengan skor $1 \%$ untuk tanda baca, skor $2 \%$ untuk ejaan, $3 \%$ untuk diksi dan kosakata, skor $4 \%$ untuk penataan kalimat, dan 5\% untuk pengembangan paragraf. Sarpika, E., Hambali, H., \& Arief, T. (2017) ada pengaruh penggunaan pembelajaran konstruktivisme pada mata pelajaran bahasa Indonesia di kelas V SD Negeri Mangasa I Kecamatan Somba Opu Kabupaten Gowa. Sari, V. N. (2014) Hasil penelitian menunjukkan bahwa pembelajaran dengan menerapkan model Discovery Learning berlangsung dengan baik. Pada siklus 1, aktivitas pembelajaran mencapai 88,94\% dan siklus II sebesar 91,045\%, mengalami peningkatan sebesar 2,105\% dengan nilai ketercapaian $\geq 80$. Pada siklus I rata-rata ketuntasan hasil belajar menulis teks cerita petualangan mencapai 79,36 dengan persentase ketuntasan klasikal mencapai 73,07\%. Pada siklus II rata-rata ketuntasan mencapai 84,09 dengan persentase ketuntasan klasikal mencapai 84,61\%, mengalami peningkatan sebesar 11,54\%. Kendala- kendala yang dihadapi, dalam siklus I maupun siklus II telah dapat diatasi dengan baik. Hasil penelitian yang lain menyatakan bahwa dengan menggunakan model Discovery Learning hasil kemampuan koneksi matematis siswa lebik baik daripada hasil kemampuan koneksi matematis siswa dengan menggunakan metode konvensional (Ismunandar, 2018) 
Berdasarkan penelitian sebelumnya menunjukkan bahwa penggunaan discovery learning dapat meningkatkan kemampuan menulis. Namun, penelitian tersebut belum ada yang berbantuan dengan teknologi tertentu. Pada konteks penelitian ini discovery learning berbantuan dengan aplikasi wemoji. Aplikasi wemoji menekankan pada pemaduan gambar dan grafis untuk mengungkapkan keinginan dalam bentuk tertulis satu kalimat. Penggunaan aplikasi tersebut karena siswa kelas VII baru lepas dari SD, masih kental sekali sifat bermain. Bermain sambil belajar untuk mencintai menulis dapat distimulus dengan cara sederhana. Oleh karenanya pemanfaatan aplikasi wemoji sebagai teknik pembelajaran di kelas, akan mengarahkan siswa pada kemanfaatan gawai android untuk pembelajaran yang positif. Pembelajaran awal teks deskriptif mengenalkan dahulu kalimat sederhana. Selama ini sticker yang mereka tahu hanya dari salin tempel (copy-paste) dan juga hanya untuk bersenang-senang. Siswa belum banyak yang tahu cara membuat stickernya. Oleh karena itu, penelitian ini siswa diajak bermain membuat sticker sederhana sekaligus menyisipkan tulisan berciri teks deskriptif materi building. Jadi penjalaran critical thinking dan transfer knowledge sebagai ciri kurikulum 2013 berlangsung dengan sendirinya atau secara inheren dalam pemelajaran yang dibingkai melalui pembelajaran berbantuan digital dengan aplikasi wemoji.

\section{METODE PENELITIAN}

Jenis penelitian yang digunakan yakni penelitian tindakan kelas. Penelitian Tindakan Kelas adalah tindakan cerdas yang dilakukan guru atau berprinsip smart, maksudnya dari kata smart mengandung pengertian specific (khusus), managable (dapat dilaksanakan), acceptable (dapat dicapai), realistic (kegiatan nyata) dan time-bound (dalam batas tertentu) menurut Arikunto (2011:11). Tindakan yang dilakukan berupa discovery learning terbimbing berbantuan aplikasi wemoji untuk basic. Penelitian ini dilakukan di salah satu SMP Negeri yang ada di Depok pada siswa kelas VII-B. Partisipipan yang terlibat berjumlah 35 siswa di semester ganjil. Terdiri dari 18 siswa lakilaki dan 17 siswa perempuan. Prosedur yang diterapkan adalah meminta siswa untuk mengunduh terlebih dahulu aplikasi wemoji dari play store gawai pintar. Guru menjelaskan cara mengoperasikan aplikasi wemoji dari mengunduh foto baik memotret sendiri atau

Diterbitkan oleh: 
mengambil dari album foto di gawai pintar atau berselancar dari internet google. Dan selanjutnya meminta siswa menyelaraskan tulisan dengan pilihan building yang diinginkan dalam bentuk kalimat. Adapun aturan dalam menulis guru menjelaskan secara singkat dalam unsur kebahasaan this atau that, to be,pemakaian article dan noun, singular atau plural seperti contoh sederhana berikut: This is a hotel. Kalimat yang sudah terbangun bersama gambar building dikirim melalui whatsapp ke guru dan meminta siswa untuk bercakap-cakap sederhana secara tertulis dalam Bahasa Inggris yang direspon guru sebagai bentuk apresiasi atas pemelajaran siswa di kelas.

Selanjutnya diambil data tes tertulis uraian singkat di pertemuan 3 pada dua siklus yang berlangsung, data tes awal sebagai acuan untuk mengaplikasikan model pembelajaran ini berhasil atau tidak dalam menelisik kemampuan menulis siswa pada teks deskriptif, data lembar observasi dan kuesioner. Adapun data penelitiaan dianalisis secara deskriptif yang dihitung menggunakan rumus cara menghitung skor setiap aspek dengan rumus menurut Arikunto (2003:57):

$$
P=\frac{f}{n} x 100 \%
$$

Keterangan :

$\mathrm{P}=$ Persentase

$\mathrm{f} \quad=$ Fekuensi yang ada pada katagori tertentu

$\mathrm{n}=$ Jumlah total atau keseluruhan jumlah subjek

Selanjutnya dibuatkan penskoran seperti pada tabel berikut:

Tabel 1 Kriteria Penskoran Lembar Observasi Siswa

\begin{tabular}{clc}
\hline Huruf & Kriteria & Persentase \\
A & Sangat Baik & $81 \%-100 \%$ \\
B & Baik & $61 \%-80 \%$ \\
C & Cukup & $41 \%-60 \%$ \\
D & Kurang & $21 \%-40 \%$ \\
E & Kurang sekali & $0 \%-20 \%$ \\
\hline
\end{tabular}

Indikator keberhasilan bahwa siswa telah menguasai kemampuan menulis melalui pengejawantahan model pembelajaran ini berhasil adalah melalui penghitungan skor sebagai berikut : 


$$
\mathrm{NA}=\frac{\text { Skor perolehan }}{\text { Skor maksimum }} \mathrm{X} 100 \%
$$

KKM yang ditentukan yakni 70 untuk KKM sekolah. Oleh karenanya penerapan model pembelajaran berbantuan digital melalui teknik pemanfaatan aplikasi wemoji dikatakan berhasil jika persentase keaktifan siswa lebih besar atau sama dengan $70 \%$, dikatakan tidak berhasil jika persentase keaktifan kurang dari 70\%, demikian juga dengan guru dikatakan berhasil bila skor perolehan mencapai lebih besar atau sama dengan $70 \%$.

\section{TEMUAN PENELITIAN DAN PEMBAHASAN}

\section{Temuan Penelitian}

\section{Deskripsi Awal Data}

Kondisi awal kemampuan siswa pada mata pelajaran Bahasa Inggris masih belum memadai dan kurang menantang siswa karena minimnya fasilitas sekolah yang mendukung pembelajaran, meskipun sekolah berada di kota dan rata-rata siswa berasal dari keluarga berpendidikan. Oleh karenanya peneliti menganggap harus ada inovasi baru yang menyenangkan dan dapat dengan mudah diakses siswa secara langsung dan efektif menunjang basic kemampuan menulis teks desktiptif. Terlebih peneliti sedang mengikuti PKP saat itu. Banyak faktor yang memengaruhi siswa sehingga pembelajaran kurang memadai selain minimnya fasilitas sekolah yakni suasana kelas yang monoton, kejenuhan karena teknik pembelajaran yang tidak variatif, pembelajaran yang dianggap siswa sulit tak memiliki waktu untuk menggali pembelajaran, tidak berinisiatif bertanya maupun berani berpendapat, dan yang masih melekat adalah kebiasaan membaca-menulis masih rendah.Tak mampu menuangkan ide dalam bentuk tertulis. Belum mengenal pembelajaran secara baik dan koheren.

Sedangkan hasil awal angket yang disebarkan pada siswa menunjukkan bahwa siswa suka terhadap pelajaran Bahasa Inggris, hanya siswa malas membaca wacana. Tidak mengerti sama sekali karena bukan bahasa ibunya. Siswa memiliki kejenuhan dengan suasana kelas yang kurang variatif dan metode yang monoton. Ada anggapan Bahasa Inggris sulit untuk dipahami karena bacaan yang panjang dan tak menarik minat bagi siswa. Pembelajaran Bahasa Inggris tak menantang bagi siswa karena kelesuan terhadap

Diterbitkan oleh: 
barisan kata-kata yang terlalu serius. Sukar dalam menelisik isi dari wacana karena hilangnya perhatian dan malu bertanya pada guru dan tak tahu artinya karena bahasa orang lain. Namun demikian yang paling penting adalah kebiasaan membaca belum membudaya di masyarakat kita terlebih pada siswa. Sehingga menulis sebagai saudara kandung membaca dianggap sulit, karena terbatasnya ide untuk menuangkan pikiran.

Kegiatan menulis belum dianggap sebagai kegiatan kreatif sehingga menjumpai kesulitan di dalamnya. Dalam benak siswa menulis hanyalah yang serius dan berbentuk wacana atau paragrap yang banyak lebih-lebih berbahasa Inggris. Menulis dipandang semakin membuat siswa alergi dan lesu karena seperti membaca peta buta akibat ketidak tahuan kosa kata dan khawatir salah membangun tulisan. Oleh karenanya pengejawantahan aplikasi wemoji adalah upaya dasar untuk memantik minat menulis teks deskriptif berbahasa Inggris pada siswa di kelas. Dengan pembelajaran berbantuan digital baik aplikasi wemoji, whatsapp dan power point, siswa tertarik untuk memampukan keterampilannya menulis secara menyenangkan dan langsung sesuai jamannya atau pembelajaran berciri PAIKEM GEMBROT.

\section{Hasil Tes}

\section{a. Hasil Tes Awal}

Sebelum mengikuti proses pembelajaran dengan menggunakan model pembelajaran berbantuan digital melalui aplikasi wemoji pada kompetensi dasar menulis teks deskriptif diberikan tes uraian singkat sebanyak 5 soal dan diperoleh hasil sebagai berikut:

Tabel 2 Hasil Pre Test Siklus I Pertemuan 1

\begin{tabular}{|c|c|c|c|c|}
\hline $\begin{array}{l}\text { Nilai } \\
\text { rata-rata }\end{array}$ & $\begin{array}{l}\text { Daya } \\
(\%)\end{array}$ & Serap & KKM & $\begin{array}{l}\text { Ketuntasan } \\
(\%)\end{array}$ \\
\hline 67,33 & & 65,53 & 70 & 68,57 \\
\hline
\end{tabular}

Melihat hasil tindakan pada pertemuan 1 ini siswa masih belum menunjukkan penguasaan kemampuan menulis yang berarti dari pembelajarannya pada menulis teks deskriptif yakni ketuntasan masih di bawah KKM yakni hanya berkisar 24 orang dengan 
persentase $68,57 \%$. Dapat kita lihat dari pembacaan grafik di bawah ini masih belum memuaskan karena masih di bawah KKM yang diharapkan yakni 70 .

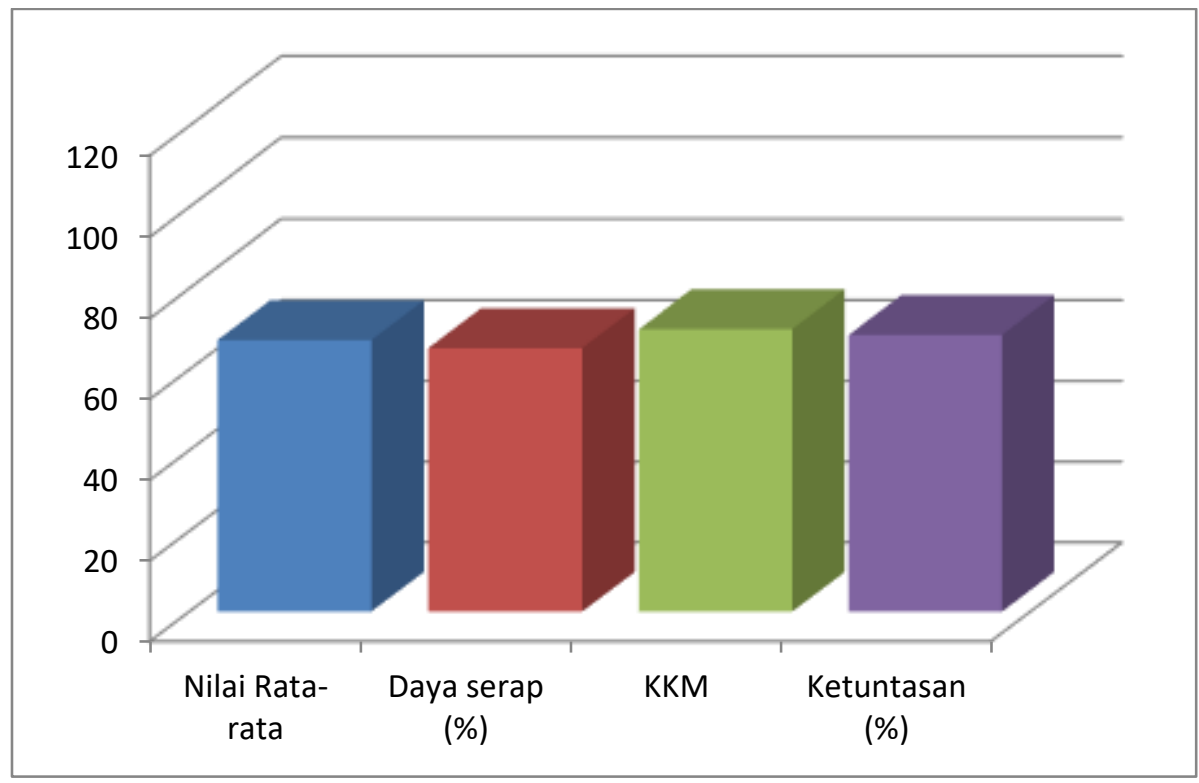

Gambar 1. Grafik Pencapaian Pre Test Siklus I

\section{b. Hasil Tes Akhir}

Setelah mengikuti proses pembelajaran dengan menggunakan model pembelajaran berbantuan digital melalui aplikasi wemoji pada kompetensi dasar menulis teks deskriptif diberikan tes uraian singkat sebanyak 10 soal dan diperoleh hasil sebagai berikut:

Tabel 3 Hasil Post Test SiklusII Pertemuan 3

\begin{tabular}{|c|c|c|c|}
\hline $\begin{array}{l}\text { Nilai } \\
\text { rata-rata }\end{array}$ & $\begin{array}{l}\text { Daya Serap } \\
(\%)\end{array}$ & KKM & $\begin{array}{l}\text { Ketuntasan } \\
(\%)\end{array}$ \\
\hline 76,4 & 76,4 & 70 & 80 \\
\hline
\end{tabular}

Akhir dari penelitian tindakan yakni pertemuan 3 siklus II sudah tampak peningkatan hasil belajar yang cukup signifikan dari siswa yakni 76,4\% dan mengalami kenaikan persentase ketuntasan sebesar $80 \%$. Artinya ada sekitar 28 siswa yang sudah tuntas belajarnya dalam kelas menulis teks deskriptif sederhana. Hal ini berimplikasi bahwa penerapan model pembelajaran berbantuan digital melalui aplikasi wemoji cukup berhasil menaikan hasil belajar siswa kelas VII-B pada kompetensi dasar menulis teks

Diterbitkan oleh: 
deskriptif sederhana di SMP Negeri 4 Depok. Bisa dilihat juga dari grafik berikut peningkatannya:

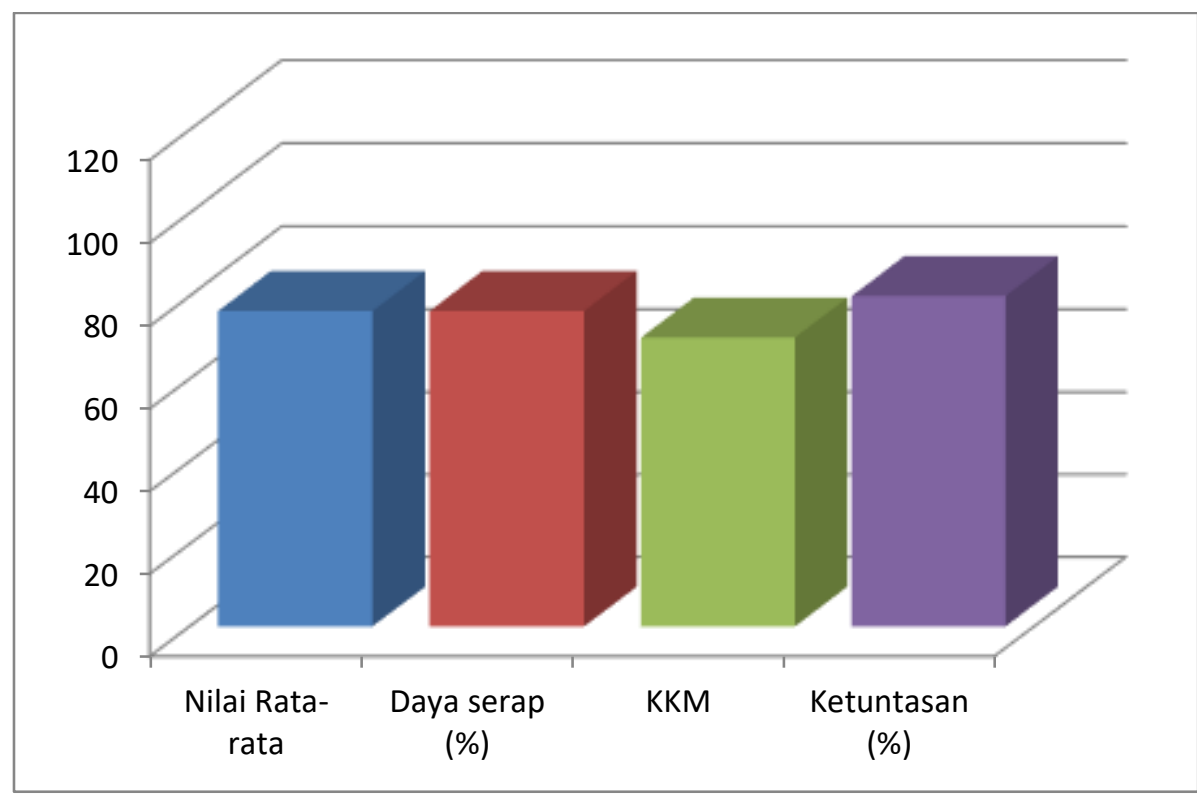

\section{Gambar 2.Grafik Pencapaian Post Test SiklusII Pertemuan 3}

Selain dari tabel juga dapat kita lihat dari beberapa foto percakapan di whatsapp tulisan berupa sticker berisi teks deskriptif sederhana yang dibuat siswa kelas VII-B di salah satu SMP Negeri di Depok yang dikirimkan kepada guru Bahasa Inggris di grup kelas, sebagai berikut:

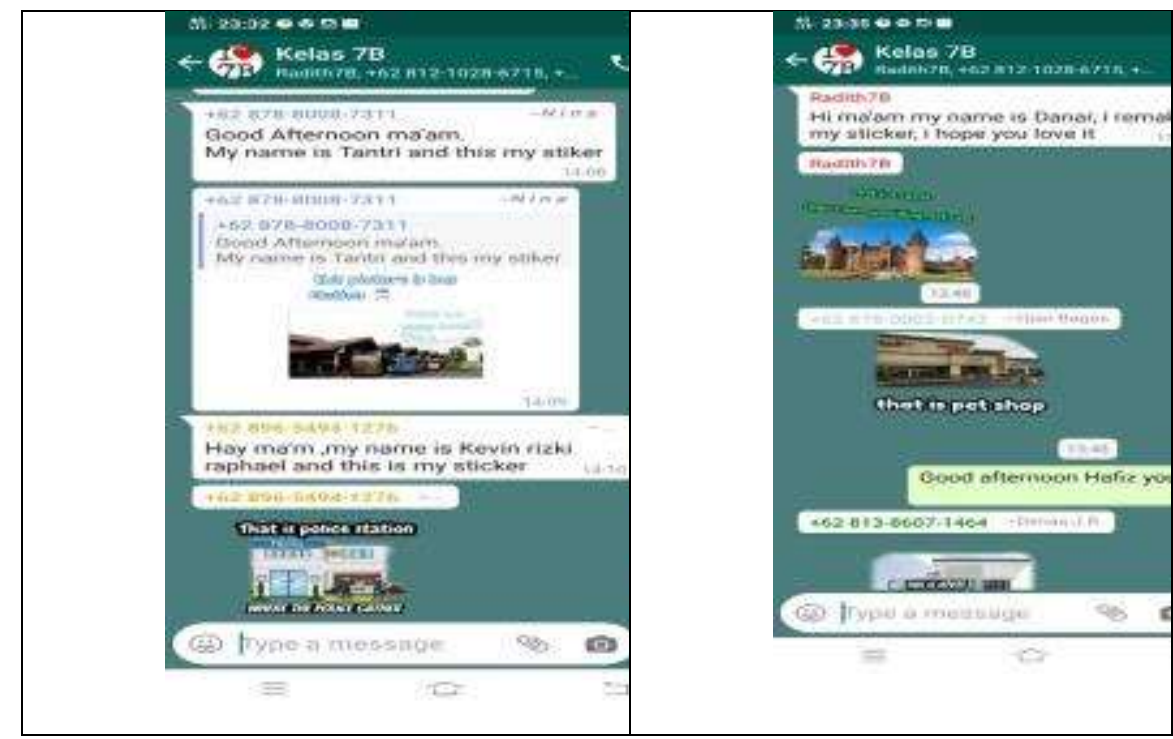

Diterbitkan oleh:

Universitas Wiralodra

Jln. Ir. H. Juanda Km 3 Indramayu, Jawa Barat 


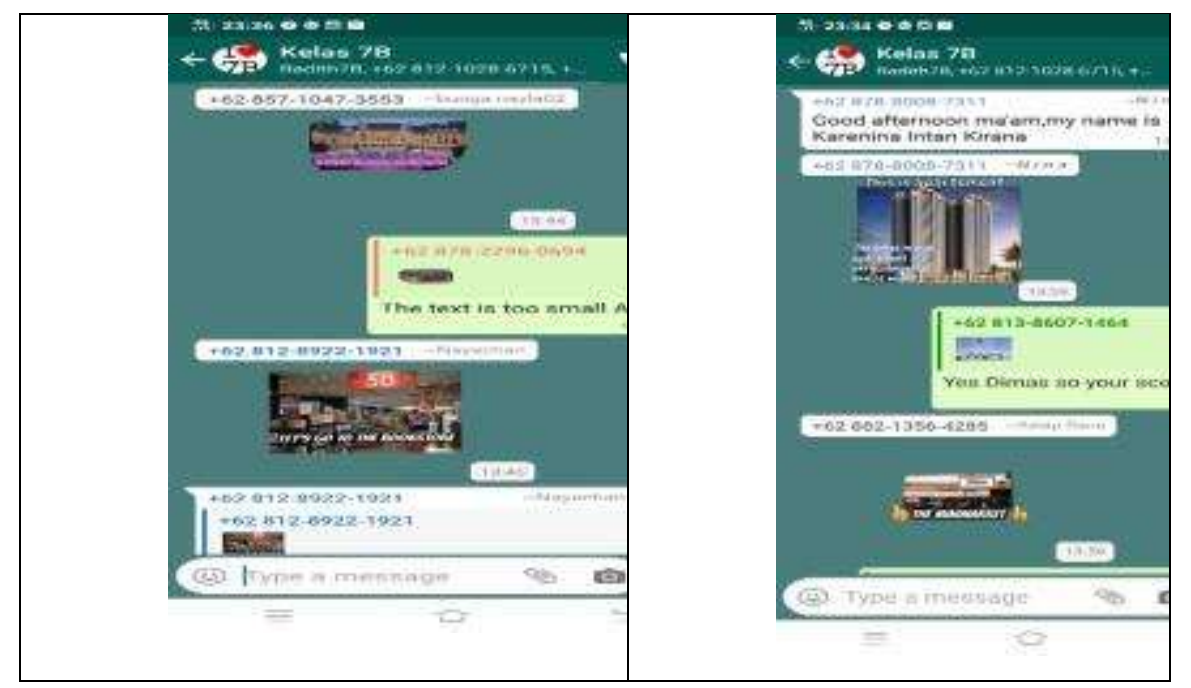

Gambar 3. Hasil Tulisan Teks Deskriptif Siswa Berupa Sticker

Berdasarkan foto-foto tersebut dapat kita tarik kesimpulan bahwa siswa dapat melatih dirinya dan memperbaiki tulisan yang sudah dibuatnya bilamana terdapat kesalahan karena adanya transfer ilmu yang diamati siswa secara inheren terbangun. Siswa saling berkolaborasi dan mengkritisi sendiri atas tulisan bergambar atau sticker yang dibuatnya dan terbentuk pemahaman yang terstimulus secara baik dan signifikan.

\section{c. Hasil Penelitian Non Tes}

Hasil penelitian non tes dari model pembelajaran berbantuan digital melalui aplikasi wemoji diperoleh sebagai berikut:

Tabel 4 Penguasaan Piranti Pembelajaranpada Siklus II Pertemuan 3

\begin{tabular}{clcc}
\hline No. & Komponen Yang Diamati & Jumlah & Persentase \\
\hline 1 & Isi Tulisan Teks Deskriptif & 30 & 85,71 \\
\hline 2 & Penulisan Kalimat & 29 & 82,86 \\
\hline 3 & Unsur Kebahasaan & 31 & 88,57 \\
\hline 4 & Kreativitas & 33 & 94,29 \\
\hline 5 & Design Sticker & 32 & 91,43 \\
\hline
\end{tabular}


Pada akhir dari siklus II, pada penelitian non tes tampak penguasaan keterampilan menulis teks dsekriptif sederhana melalui model pembelajaran berbantuan digital dengan aplikasi wemoji mencapai peningkatan yang sangat baik yakni sebesar $88,57 \%$. Siswa mengalami aktivits pemelajaran yang saling mendukung terjadi kolaborasi di kelas dengan rekan sejawat dalam berselancar dan saling melihat hasil temannya di grup whatsapp, sehingga pencapaian keberhasilan belajar sangat baik terlihat.

Hal ini juga dapat dilihat dari grafik di bawah ini keaktifan siswa sangat baik dan menggembirakan baik bagi siswa sendiri juga guru:

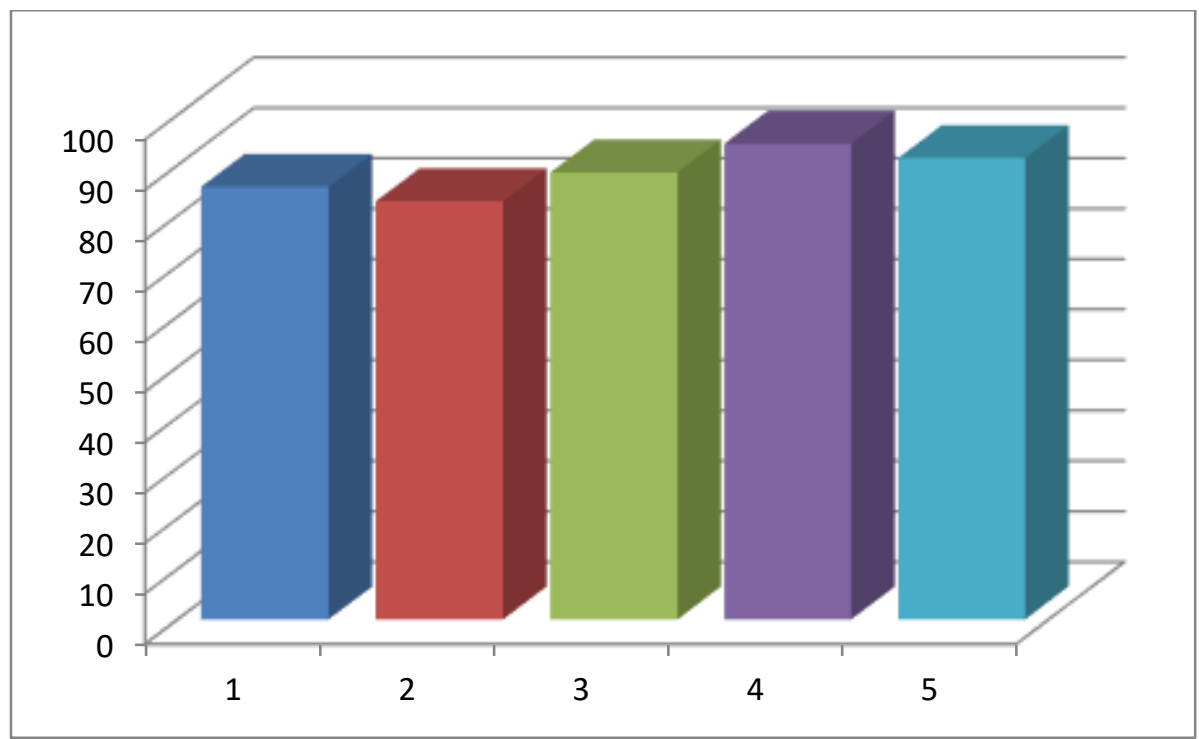

\section{Gambar 3.Grafik Penguasaan Piranti Pembelajaransiklus II pertemuan 3}

Keaktifan siswa berselancar dan membangun pemelajarannya dapat kita perhatikan dari foto-foto berikut: 


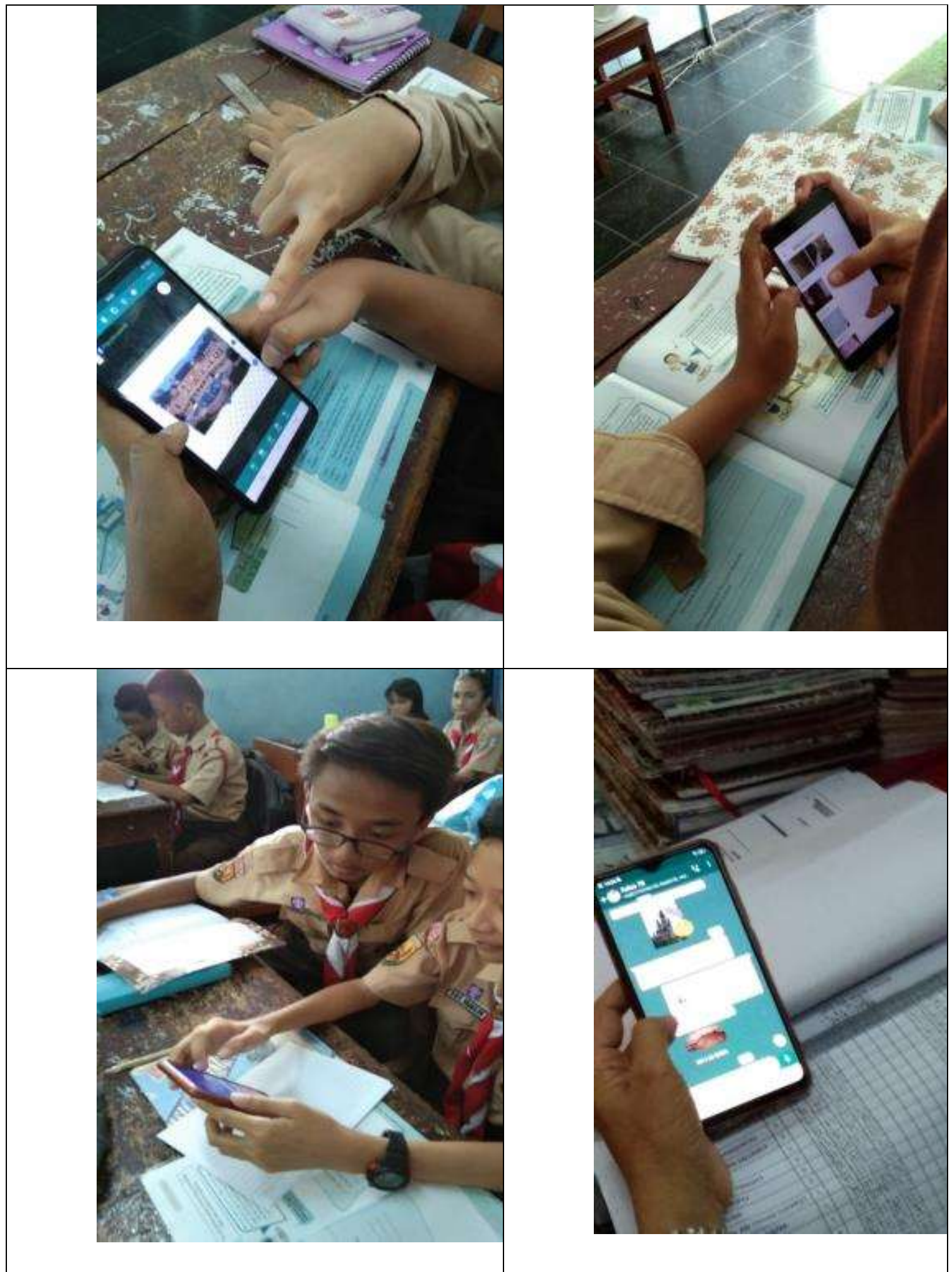

Gambar 4. Kegiatan Siswa dalam Pembelajaran Berbantuan Digital dengan

Aplikasi Wemoji 
Tampak kegiatan non tes, siswa dalam keadaan melakukan 4C (communication, collaboration, critical thinking and problem solving dan creative and innovative). Pembelajaran dirasakan siswa menjadi menyenangkan yang ditampakkan dalam antusiasme menyerap pembelajaran berupa tulisan teks deskriptif sederhana.

\section{Pembahasan}

Berdasarkan hasil penelitian diperoleh adanya peningkatan kemampuan menulis teks sederhana. Hal tersebut selaras dengan hasil penelitiannya Rahayu (2017) menunjukkan bahwa penggunaan media pembelajaran LSB dapat meningkatkan kemampuan menulis Bahasa Inggris pada monolog teks (Recount Text dan Narrative Text) pada peserta didik kelas VIII-B MTs Negeri Gondowulung. Hasil nilai rata-rata menulis mengalami peningkatan yaitu 75,48 pada siklus I dan 76,94 pada siklus II. Hasil ini sudah mencapai nilai target yang ditentukan dalam penelitian yaitu 75. Jumlah peserta didik yang mencapai ketuntasan mengalami kenaikan yaitu $71 \%$ pada siklus I dan $80,6 \%$ pada siklus II. Jumlah peserta didik yang mencapai nilai ketuntasan sudah mencapai target yaitu $80 \%$. Tingkat partisipasi aktif peserta didik mencapai $83,9 \%$ pada siklus I dan $87,1 \%$ pada siklus II. Hasil ini menunjukan partisipasi aktif sudah melampaui target yaitu $85 \%$. Yusnidar, Y. (2016) menyimpulkan bahwa penerapan metode Gallery Walk dapat meningkatkan kemampuan siswa menulis teks analytical exposition bahasa Inggris. Maryani, S., Nengah, M., \& Gede, A. (2013) Hasil yang diperoleh: (1) langkah-langkah pembelajaran dengan menggunakan media gambar, antara lain; Menjelaskan materi tentang menulis teks berita, memperkenalkan media gambar, membagikan media gambar, menjelaskan penggunaan media gambar dalam pembelajaran menulis teks berita, memberikan contoh menulis teks berita, menugaskan siswa mengamati gambar yang telah dibagikan, menugaskan siswa untuk menulis teks berita, mengumpulkan hasil menulis teks berita siswa, mengadakan refleksi dan menyimpulkan pelajaran yang telah dilakukan. (2) terjadi peningkatan kemampuan menulis teks berita pada siswa, dari skor rata-rata kemampuan siswa sebelum tindakan 60,12 meningkat menjadi 63,24 pada siklus I dan meningkat lagi menjadi 73,91 pada siklus II. (3) 93,94\% siswa memberikan respon sangat positif terhadap penggunaan media gambar dalam pembelajaran menulis teks berita. 
Hal ini memenuhi kriteria ciri pembelajaran 2013 yakni 4C: (1) Communication (2) Collaboration, (3) Critical Thinking and problem solving, dan (4) Creative and Innovative. Siswa membangun tulisan kalimat yang kreatif tidak sama satu sama lain memenuhi kriteria penilaian seperti yang termasuk dalam tabel di atas. Siswa mengkomunikasikan gambar yang ingin dibuat sticker (unsur communication) lalu siswa berkolaborasi bagaimana membuat tulisan yang kreatif baik isi tulisan atau pun warna dan bentuk tuisan dari sticker (unsur collaboration). Siswa membaca hasil teman yang sudah mengirim di whatspp grup jika kurang baik direspon guru, siswa dengan cepat membuat lagi dan membenahi kesalahan yang dibuat (tampak siswa antusias dan senang melakukannya dengan kata lain terjadi unsur ketiga yakni critical thinking dan problem solving oleh siswa itu sendiri). Serta hasil yang dibuat menunjukkan tingkat kreativitas yang baik dalam pembuatan sticker yang positif. Kombinasi tulisan dengan gambar dibuat secara inovasi dan siswa lancar menggunakan digitalnya, dengan artian siswa sangat senang belajar dalam teknik yang dibingkai guru di kelas (unsur $\mathrm{C}$ keempat yakni creative dan innovative).

Pembingkaian pembelajaran berbantuan digital dengan aplikasi wemoji mampu mengajak serta menstimulus siswa untuk belajar secara aktif dan terlibat di dalam mengkonstruk sendiri pembelajarannya atau merdeka belajar sesuai arahan Menteri Pendidikan Nadiem Makarim. Siswa aktif serta bekerja secara terintegrasi penalaran kreatifnya di dalam model pembelajaran di kelas.

\section{KESIMPULAN}

Berdasarkan uraian hasil analisis penelitiaan baik dari tes maupun non tes beberapa simpulan yang dapat ditarik adalah: Pertama, adanya penguasaan kemampuan menulis teks deskriptif sederhana baik melalui tes maupun non tes, yakni adanya peningkatan kemampuan menulis siswa sebesar $76,4 \%$ dalam hasil tes serta ketuntasan $80 \%$, dikatagorikan hasilnya baik. Artinya 28 siswa tuntas serta mampu menguasai teks deskripsi sederhana dalam satu kalimat yang tertuang dan aktivitas penguasaan pembelajaran dicapai sebesar $88,57 \%$. Hal ini berkatagori sangat baik. Kedua, melalui model pembelajaran berbantuan digital dengan aplikasi wemoji dapat menstimulus siswa untuk mampu menulis teks deskriptif sederhana secara kreatif. Pembelajaran yang terkelola dengan baik pada

Diterbitkan oleh:

Universitas Wiralodra

Jln. Ir. H. Juanda Km 3 Indramayu, Jawa Barat 
kelas rendah di sekolah menengah mampu menghantarkan siswa mengembangkan penalaran lateralnya menjadi penalaran imajinatif-aplikatif menuju penalaran kreatif yang berimbas pada hasil belajar yang baik yakni hanya 7 siswa yang masih ada di bawah KKM serta memenuhi unsur 4C sebagai ciri pembelajaran kurikulum 2013 dan merdeka belajar seperti yang disinggung menteri Nadiem Makarim sesuai jamannya. Keitga, melalui pembelajaran berbantuan digital dengan aplikasi wemoji dapat melatih siswa berpikir HOTS. Karena ciri manusia pada dasarnya adalah ada rasa tidak puas dan bersaing bila ada yang lebih bagus sticker-nya. Apalagi dengan memegang gawai pintar siswa terpenuhi rasa ketidak puasannya terhadap sticker yang kurang baik dalam gambar maupun tulisan dan berusaha untuk memperbaikinya dengan cepat dan efektif. Terjadilah Amati Tiru Modifikasi (ATM) pada siswa di kelas. Ditambah apresiasi siswa sendiri terhadap temannya atau guru yang mendorong untuk membuat lebih baik lagi, jika dirasa belum memenuhi aturan kepenulisan teks deskriptif. Sehingga berpikir HOTS terjadi secara inheren dalam pemelajaran yang terpola di dalam kelas.

\section{DAFTAR PUSTAKA}

Slavin, R. E. "Student-centered and constructivist approaches to instruction" Educational Psychology: Theory and Practice (2006): 241.

Chin, C \& Osborne, J. (2008). Students' questions: a potential resource for teaching and learning science. Studies in Science Education, Vol 44, No 1, 1-39, DOI: 10.1080/03057260701828101

Idalia Cardoso. (2017). Penerapan Metode Konstruktivisme Untuk Meningkatkan Kemampuan Menulis Narasi Siswa Kelas VII SMPN Satap Heut'utan. Jubindo: Jurnal Ilmu Pendidikan Bahasa dan Sastra Indonesia, Vol 3, No 2, Agustus 2018.

Ismunandar, D. (2018). Pembelajaran Menggunakan Model Discovery Learning Terhadap Kemampuan Koneksi Matematik. Prosiding SNMPM II, 193-201.

Sarpika, E., Hambali, H., \& Arief, T. (2017). Pengaruh Pembelajaran Konstruktivisme terhadap Kemampuan Menulis Siswa pada Mata Pelajaran Bahasa Indonesia Kelas V SD Negeri Mangasa I Kecamatan Somba Opu Kabupaten Gowa. JKPD (Jurnal Kajian Pendidikan Dasar), Vol 2, No 1, 204-218.

Diterbitkan oleh: 
Sari, V. N. (2014). Penerapan model discovery learning sebagai upaya meningkatkan kemampuan menulis teks cerita petualangan siswa kelas IV sekolah dasar. Jurnal Penelitian Pendidikan Guru Sekolah Dasar, Vol 2, No 2, 1-10.

Rahayu, E. (2017). Peningkatan Kemampuan Menulis Monolog Teks Bahasa Inggris dengan Menggunakan LSB pada Peserta Didik Kelas VIII-B MTsN Gondowulung Bantul. Jurnal Pendidikan Madrasah, Vol 2, No 1, 197-208.

Yusnidar, Y. (2016). Penerapan Metode Gallery Walk untuk Meningkatkan Kemampuan Menulis Teks Analytical Exposition Bahasa Inggris Siswa Kelas XI IPA-1 MAN Model Banda Aceh. Getsempena English Education Journal, Vol 1, No 2.

Maryani, S., Nengah, M., \& Gede, A. (2013). Penggunaan Media Gambar Untuk Meningkatkan Kemampuan Menulis Teks Berita Siswa Kelas VIII SMPN 4 Soromadi Kabupaten Bima NTB. Jurnal Pendidikan dan Pembelajaran Bahasa Indonesia, 2.

Arikunto, S., \& Jabar, C. S. A. (2004). Evaluasi program pendidikan pedoman teoritis praktis bagi praktisi Pendidikan. Jakarta: Bumi Aksara. 